\title{
Ten Years of Paleoceanographic Studies at ODP Site 963 (Central Mediterranean Sea)
}

\author{
Enrico Di Stefano, Alessandro Incarbona*, Rodolfo Sprovieri and Serena Ferraro
}

Università degli Studi di Palermo, Dipartimento di Scienze della Terra e del Mare, Via Archirafi 22, 90134 Palermo, Italy

\begin{abstract}
The geographical location, the shape and the circulation pattern makes the Mediterranean Sea an ideal laboratory to study the interplay between different climatic systems, abrupt climate changes and the response of marine ecosystems. The Ocean Drilling Program Site 963 was drilled in the Northwestern part of the Sicily Channel, the sill that divides the western from the eastern Mediterranean Sea. Numerous papers have been published on Site 963 sediments in the last decade, investigating Mediterranean paleoceanographic themes. Here we offer a synthetic framework of these investigations carried out by sub-centennial resolution. We present the whole sequence of suborbital climatic oscillations over the last $130 \mathrm{kyr}$, that is since the last interglacial period, and we claim that teleconnection with Greenland and North Atlantic regions is the most likely phenomenon to explain our results. Furthermore we show the high sensitivity of marine planktonic (planktonic foraminifera and coccolithophores) ecosystems to Stadial/Interstadial fluctuations. We conclude that a three-steps scenario may describe productivity variations during each high-frequency oscillation, from Interstadial 24 to the last deglaciation (from 110 to 15 kiloyears ago): surface oligotrophy and a deep nutricline in the lower part of Interstadials; increased productivity, through a deep chlorophyll maximum and winter/spring coccolithophore blooms, during the upper part of Interstadials; a shallow nutricline during Stadials and possibly reduced productivity levels with respect to the upper Interstadial phase. Results from Site 963 investigations provide key information for very highresolution paleoceanographic research in the Mediterranean Sea.
\end{abstract}

Keywords: Coccolithophores, late quaternary, mediterranean sea, planktonic foraminifera.

\section{INTRODUCTION}

Since the recovery of sapropel layers in the eastern Mediterranean sediments [1], the paleoceanographic research in the region was especially devoted to the comprehension of processes that led to bottom anoxia. Currently, nutricline dynamics and paleoproductivity levels [2-4] and the impact of increased monsoon activity and runoff from North African rivers that may have caused the failure of deep water formation $[5,6]$ are among the most important topics to understand the origin of sapropels.

In spite of the geographical location, the shape of the basin and the circulation pattern, the Mediterranean basin is an ideal site to investigate the interplay between different climatic systems, abrupt climate changes and the response of marine ecosystems. Cacho et al. [7-10] published a series of papers based on the Alboran Sea sedimentary archive (core MD95-2043) that disclosed the sensitivity of the Mediterranean Sea to the last glacial suborbital climatic oscillations: the occurrence of the whole sequence of Stadials (cold water phases) and Interstadials (warm water phases) over the last 50 kiloyears (kyr), synchronized to the same events in the Northern Hemisphere (Greenland ice

*Address correspondence to this author at the Università degli Studi di Palermo, Dipartimento di Scienze della Terra e del Mare, Via Archirafi 22, 90134 Palermo, Italy; Tel: +3909123864648;

E-mail alessandro.incarbona@unipa.it cores and North Atlantic sedimentary cores); a circulation pattern strengthened during Stadials (and Heinrich events) and weakened during Interstadials, that is opposite to the Atlantic Meridional Overturning Circulation fashion; productivity levels decreased during Stadials and Heinrich events and vice versa increased during warm water phases. The work of these authors opened a new line of paleoceanographic research in the very high-resolution sedimentary record of the western and central Mediterranean Sea.

The Ocean Drilling Program (ODP) Site 963 was drilled in the Northwestern part of the Sicily Channel, the sill that divides the western and the eastern Mediterranean subbasin. This area is nowadays very sensitive to modifications in the Mediterranean thermohaline circulation [11, 12] and, for many reasons, suitable for paleoceanographic research: the very high-sedimentation rate of Site 963, specifically between 18.0 and $50.0 \mathrm{~cm} / \mathrm{kyr}$ over the last $130 \mathrm{kyr}$ [13-16]; the flow of Levantine Intermediate Water (LIW) at the sea floor, a key water mass for understanding Mediterranean oceanographic dynamics; the middle-latitude location, suitable to provide information on the interaction among different climatic systems.

Since the study of Sprovieri et al. [13], dealing with calcareous plankton ecobiostratigraphy during the last 18 kyr, numerous papers have been published on Site 963 sediments, investigating Mediterranean paleoceanographic themes. They are listed in Table $\mathbf{1}$. Here we offer a synthetic 
Table 1. List of papers published on Site 963 material and dealing with paleoceanographic themes. From the left, the bibliographic reference; the main issue of the work; the time interval of the examined cores.

\begin{tabular}{|c|c|c|c|}
\hline S, no & Bibliographic Reference & Issue & Time Domain (ka) \\
\hline \hline 1$)$ & Sprovieri et al. (2003) & Paleoclimate/ Ecobiostratigraphy & $20-0$ \\
\hline 2$)$ & Di Stefano and Incarbona (2004) & Paleoenvironment & $130-70$ \\
\hline 3$)$ & Sprovieri et al. (2006) & Paleoclimate & $11-0$ \\
\hline 4$)$ & Incarbona et al. (2008a) & Paleoenvironment & $400-0$ \\
\hline 5$)$ & Incarbona et al. (2008b) & Ecobiostratigraphy & $130-70$ \\
\hline 6$)$ & Incarbona et al. (2009) & Paleoclimate/ Paleoenvironment & $400-0$ \\
\hline 7$)$ & Incarbona et al. (2010) & Paleoenvironment & $130-110$ \\
\hline 8$)$ & Di Stefano et al. (2010) & Paleoenvironment & $130-110$ \\
\hline 9$)$ & Censi et al. (2010) & Paleoceanography & $70-20$ \\
\hline 10$)$ & Incarbona et al. (2011) & Paleoclimate/ Paleoceanography & $70-20$ \\
\hline 11$)$ & Sprovieri et al. (2012) & Paleoenvironment/ Paleoproductivity & \\
\hline 12$)$ & Incarbona et al. (2013) & & \\
\hline
\end{tabular}

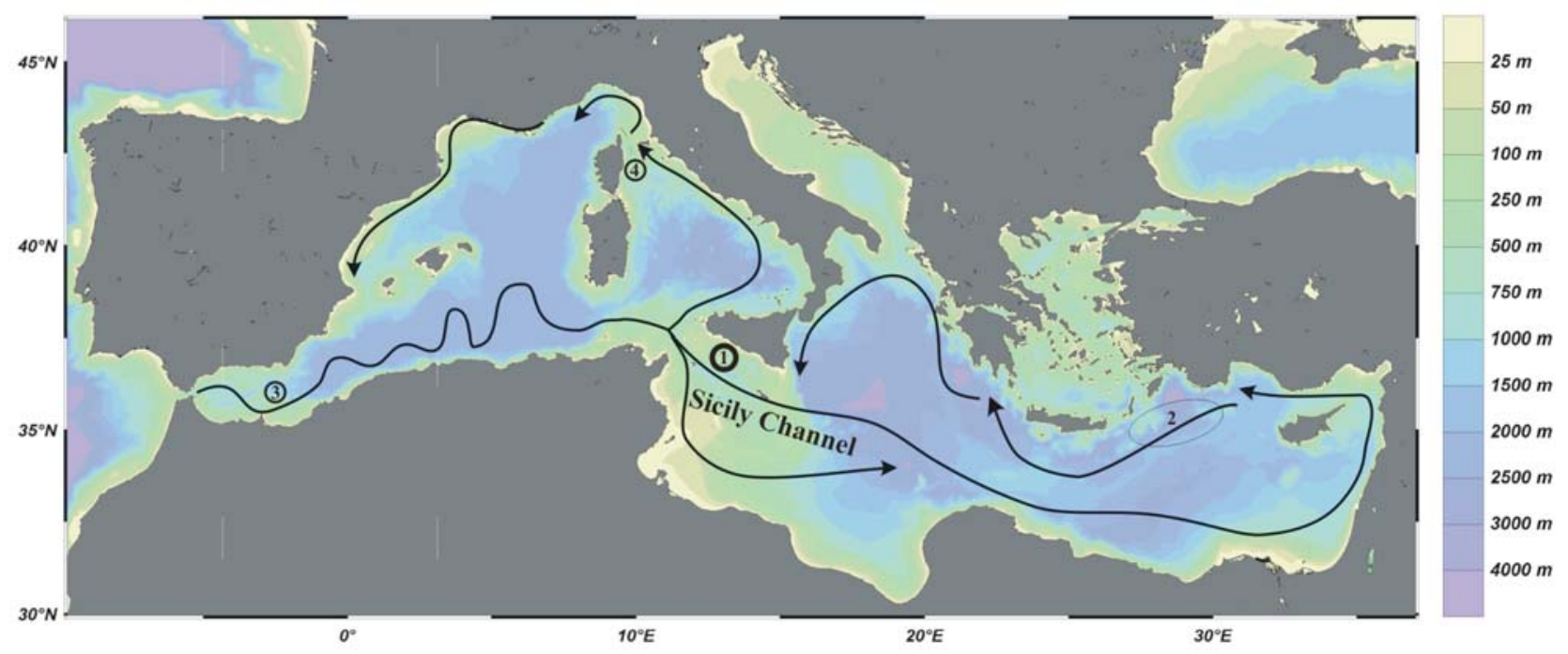

Fig. (1). Bathymetric map of the Mediterranean Sea, surface water circulation in winter [17, 23] and Mediterranean cores' location. Black circles and ellipses indicate: 1: ODP Site 963 cores; 2: LIW formation area [22, 23]; 3: MD95-2043 and ODP Site 977 cores [7, 51]; 4: MD01-2434 and MD01-2472 cores [60].

framework for the detectment and interpretation of suborbital climatic oscillations, focussing on the last $130 \mathrm{kyr}$, that is since the last interglacial period, and examine the response of marine ecosystems (planktonic foraminifera and coccolithophores).

\section{THE MEDITERRANEAN SEA: OCEANOGRAPHY AND CLIMATOLOGY}

\subsection{Oceanographic Circulation}

The Mediterranean is a semi-enclosed sea, with a thermohaline circulation that reproduces global ocean processes. Surface waters, called Modified Atlantic Water
(MAW), enter from the Atlantic Ocean (Fig. 1) and occupy the first 100-200 m of the water column. MAW flows and, at the entrance of the Sicily Strait, separates into two branches [17]. Into the Sicily Channel, MAW is again split into two streams, southeast of Pantelleria [18, 19]: the Atlantic Tunisian Current that reaches the African coast and flows eastwards as a coastal current [19, 20]; the northern branch, called the Atlantic Ionian Stream (AIS), that contributes to the MAW transport into the eastern Mediterranean off the southern coast of Sicily. Three semipermanent mesoscale summer features are associated with AIS meanders, mainly in response to topographical effects, the Adventure Bank Vortex (ABV), the Maltese Channel Crest and the Ionian Shelfbreak Vortex [19, 21]. 
Levantine Intermediate Water (LIW) forms in the eastern basin in winter due to surface cooling on salt-enriched water masses (Fig. 1) [22, 23]. LIW occupies a depth between 150200 and $600 \mathrm{~m}$, is ubiquitous throughout the eastern basin and enters the Sicily Channel through the sills south of Malta [21].

Dense water forms in the northern part of the basin, in the Gulf of Lions (Western Mediterranean Deep Water WMDW) and in the Adriatic and Aegean Sea (Eastern Mediterranean Deep Water - EMDW). The dense water formation process starts with the blowing of very cold and dry air masses (Mistral, Bora and Etesian) which causes deep convection throughout the water column. Surface water mixes with LIW and fill the sea bottom. In recent epochs, EMDW and WMDW have never been in touch, because of the topographical barrier constituted by the Sicily Channel.

\subsection{Nutrient Dynamics}

The trophic resources of the Mediterranean Sea are among the poorest in the world's oceans. The anti-estuarine circulation pattern contributes to its maintenance, since, at the Strait of Gibraltar, surface waters coming from the Atlantic Ocean are nutrient depleted, with respect to outflowing waters, mainly constituted by LIW [24, 25]. A significant West-East trophic gradient, with a nutrient depletion (especially phosphorus) and a reduction in primary productivity in the eastern basin for over 3 times, has also been reported [26, 27].

Changes in primary production and dynamics of the water column are seasonally controlled. The winter convection, and less frequent frontal zones or upwelling areas, bring nutrients into the photic zone (mesotrophic regime). An oligotrophic regime, characterized by a much lower level of production, occurs in summer, when a stable stratification, due to the deepening of the summer thermocline down to about $90 \mathrm{~m}$, takes place [28, 29]. The Sicily Channel falls within the 'non-blooming' area, characterized by low biomass during late spring-summer and higher biomass during late fall-winter [29].

\subsection{Atmospheric Pattern}

Most of the Mediterranean region is indirectly under the influence of North Atlantic sea surface temperature (SST), one of the most important factors that drives the atmospheric circulation pattern. Rainy westerlies provide moisture and lower the temperature in winter, whereas the penetration of the Azorean high-pressure cell in summer causes a general drought. Different modes of atmospheric variability in the North Atlantic/Europe region (e.g. the North Atlantic Oscillation and the East Atlantic pattern) may impact on dense water formation sites in the Mediterranean Sea [30].

The easternmost part of the Mediterranean basin is influenced by the seasonal shift in the position of the Intertropical Convergence Zone (ITCZ). The ITCZ is coupled to the Indian Monsoon and the zonal Tropical circulation [31], highlighting a complex interplay between high- and low-latitude components of the climate system.

\section{MATERIAL}

Hole 963A (longitude $37^{\circ} 01.938^{\prime} \mathrm{N}$, latitude $13^{\circ} 10.896^{\prime}$ E; 470.5 metres below sea level) and Hole 963D (longitude $37^{\circ} 02.148^{\prime} \mathrm{N}$, latitude $13^{\circ} 10.686^{\prime} \mathrm{E}$; 469.1 metres below sea level) were recovered in the Sicily Strait between the Adventure Bank and the Gela Basin, within the ABV area (Fig. 1). The bulk sediment composition is enriched in the terrigenous detrital matter [32] and several sapropelitic layers occur in the lowermost part of the sedimentary record $[33,34]$. Six tephra layers, associated to the Pantelleria island volcanic activity, have been identified [35]. The ODP1 tephra, corresponding to the Green Tuff and the Y-6 layer in the scheme of Keller et al. [36] falls within the sedimentary sequence here selected.

\section{METHODS}

\subsection{Coccolithophores}

Calcareous nannofossil analysis was carried out on 1121 samples [13-16, 37-39] by observation with a polarized microscope at about $1250 \mathrm{X}$ magnification. Rippled smear slides were prepared following the standard procedure [40]. A total of 300-500 specimens within the entire assemblage were analysed. Quantitative data were collected on more than 20 taxonomic units, generally following the taxonomic concepts on living coccolithophores of Young et al. [41]. Gephyrocapsids were identified to a species level when they are at least $3 \mu \mathrm{m}$ long, whereas smaller specimens were grouped into small Gephyrocapsa. Small placolihs include Reticulofenestra spp. and very small specimens of Emiliania huxleyi with slight diagenetic problems (dissolved T-shaped elements). Florisphaera profunda includes rare specimens of Gladiolithus flabellatus.

Taxa were grouped into 'placoliths', 'miscellaneous group', 'upper photic zone (UPZ) group' and 'lower photic zone. (LPZ) group on the basis of distinctive morphologies and biogeographies [42, 43]. Placoliths include E. huxleyi, small placoliths, small Gephyrocapsa, Gephyrocapsa muellerae and Gephyrocapsa oceanica. Miscellaneous group includes Helicosphaera spp., Coccolithus pelagicus, Syracosphaera histrica, Oolithotus fragilis, Pontosphaera spp., Calcidiscus leptoporus, Pleurochrysis spp., Braarudosphaera spp. and specimens of all the other species. UPZ group includes Syracosphaera pulchra, Umbellosphaera spp., Discosphaera tubifera, Rhabdosphaera spp., Umbilicosphaera spp., Calciosolenia spp., holodiscolithus, Ceratolithus spp. and the dinoflagellate Thoracosphaera heimii [44]. Finally, given the rarity of Gladiolithus flabellatus and given that Algirosphaera robusta was not found in any sample, $F$. profunda is the main species of the 'lower photic zone' (LPZ) group.

The ecological preference of groups is shown in Table 2.

\subsection{Planktonic Foraminifera}

A total of 2188 samples [13, 14, 16, 38, 39] were dried and washed on a $63 \mu \mathrm{m}$ sieve for planktonic foraminifera 
Table 2. Ecological preference of selected planktonic foraminifera species, from Hemleben et al. [46], Pujol and Vergnaud-Grazzini [73], Žarić et al. [74] and Rigual-Hernández et al. [75].

\begin{tabular}{|c|c|}
\hline Taxa & Ecological preference \\
\hline \hline G. ruber & warm and oligotrophic surface water \\
\hline N. pachyderma $\mathrm{dx}$ & Deep Chlorophyll Maximum \\
\hline T. quinqueloba & high fertility surface water \\
\hline G. bulloides & high fertility surface water \\
\hline
\end{tabular}

Table 3. Ecological preference of selected coccolithophore taxa. Bibliographic references are indicated.

\begin{tabular}{|c|c|}
\hline Taxa & Ecological Preference \\
\hline Placoliths & $\begin{array}{l}\text { r-strategist taxa [42], high surface } \\
\text { productivity [76-78] }\end{array}$ \\
\hline F. profunda & $\begin{array}{c}\text { deep nutricline }[79], \text { low prodictivity } \\
\text { levels }[15,70,72]\end{array}$ \\
\hline UPZ taxa & $\begin{array}{c}\text { K-strategist taxa [42], surface oligotrophy } \\
{[80,81]}\end{array}$ \\
\hline Miscellaneous taxa & weak tendency to K-strategist taxa [42] \\
\hline
\end{tabular}

analysis. The relative abundance of each species was obtained from splits of about 300 specimens, in the residue greater than $125 \mu \mathrm{m}$. Taxonomic concepts follow Bolli et al. [45] and Hemleben et al. [46]. Globigerinoides quadrilobatus includes Globigerinoides trilobus and Globigerinoides sacculifer. Globigerina bulloides includes Globigerina falconensis. The paleoclimate curve is the algebraic sum of warm-water species percentages ( $G$. ruber, Globigerina siphonifera, Globigerinoides quadrilobatus, Globoturborotalita rubescens, Globoturborotalita tenella) expressed as positive values and cold-water species percentages (Neogloboquadrina pachyderma, G. bulloides, Turborotalita quinqueloba, Globorotalia scitula and Globigerinita glutinata) expressed as negative values, following previous studies $[14,47]$. The ecological preference of selected taxa is shown in Table $\mathbf{3}$.

\subsection{Oxygen Isotopes}

During the last glacial period, the oxygen isotope analysis was carried out on about $5 / 10$ specimens of the planktonic foraminifera species Neogloboquadrina pachyderma (right coiling - r.c.), for a total of 522 samples, and the benthic foraminifera species Cibicidoides pachyderma, for a total of 517 samples [16]. Samples were measured in an automated continuous flow carbonate preparation GasBenchII device [48] and a ThermoElectron Delta Plus XP mass spectrometer at the IAMC-CNR (Naples) isotope geochemistry laboratory. Acidification of samples was performed at $50^{\circ} \mathrm{C}$. An internal standard (Carrara Marble with $\delta^{18} \mathrm{O}=-2.43 \%$ versus VPDB) was run every 6 samples and the NBS19 international standard was measured every 30 samples.
Oxygen isotope data were also obtained on 1 to 2 specimens of the benthic foraminifera species $C$. pachyderma (65 samples) for the whole MIS 5 and from about 10 specimens of $G$. ruber (35 samples) [14]. Measurements were made at the Woods Hole Oceanographic Institution on a Finnegan MAT353 stable isotope mass spectrometer following standard procedures [49].

\section{CHRONOLOGICAL FRAMEWORK}

The chronological framework here presented follows Sprovieri et al. [14] for the MIS 5 interval (130-70 kiloyears ago - ka), Sprovieri et al. [16] for the last glacial (70-20 ka) and Incarbona et al. [15] for the Holocene (11.6-0 ka). The age model is complemented by the correlation between the planktonic foraminifera paleoclimatic curve from data of Sprovieri et al. [13] and the Greenland ice core $\delta^{18} \mathrm{O}$ curve [50] along the last deglaciation, thus including the BollingAllerød and the Younger Dryas base.

Specifically, a peak to peak correlation has been carried out between the planktonic foraminifera paleoclimatic curve and $\delta^{18} \mathrm{O}$ data of NGRIP ice cores for the $122-70 \mathrm{ka}$ time slice and the MIS 6/MIS 5 boundary age has been imported by Martrat et al. [51]. A peak to peak correlation has been carried out between high abundance values of $G$. ruber (together with light values in the benthic and planktonic $\delta^{18} \mathrm{O}$ data) and interstadials in the Greenland Ice Core Chronology of Andersen et al. [52] and Svensson et al. [53, 54], and two calibrated radiocarbon ages for the last glacial period [16]. Finally, the Holocene chronological framework has been built on the basis of linear interpolation between six dated (calibrated radiocarbon ages) horizons [15].

Data from Holes 963A and 963D were joined in order to obtain a composite section. The first adopted criterion was based on the physical property of the section, following the indication of Sakamoto et al. [55], and in particular the distinctive peak of about 10 instrument units of magnetic susceptibility identified at $6.92 \mathrm{mbsf}$ in Hole 963A and at 7.35 in Hole 963D [56]. The latter level benefits from a radiocarbon dating, which calibrated age is $19.73 \mathrm{kyr}$ BP. The calibrated age for the depth of 6.92 mbsf at Hole 963A, deduced by linear interpolation between the two dated horizons of core $2 \mathrm{H}$, is $19.52 \mathrm{kyr} \mathrm{BP}$, which is within the error associated to the method.

The peak to peak synchronization between Greenland ice core and Mediterranean suborbital climatic fluctuations is justified by teleconnection phenomena [7, 8, 57]. Cacho et al. [7] developed two alternative age models for the last 50 kyr in the Alboran Sea, respectively based on calibrated radiocarbon datings and synchronization of alkenone-based sea surface temperatures with $\delta^{18} \mathrm{O}$ data from Greenland ice cores, which are remarkably in agreement. The ODP 963 site supports the validity of the teleconnection assumption between Mediterranean and Greenland climatic fluctuations, through the comparison of the age of ODP1 tephra, respectively estimated at $45.0 \pm 0.9 \mathrm{ka}$ by the constrain of Dansgaard-Oeschger oscillations $[16,39]$ and high resolution ${ }^{40} \mathrm{Ar} /{ }^{39} \mathrm{Ar}$ dating at $45.7 \pm 1.0$ [58].

The adopted tie-points are listed in Table 4. 
Table 4. List of the adopted tie-point used to assess the age model. From the left, the depth in mbsf; the age in ka; the indication of the tie-points' sequence. IS 2-IS 18 refers to the sequence of Interstadials, the tie-points used for the last glacial period. $\mathrm{S} 20$ $\mathbf{S} 26$ refers to the sequence of Stadials, the tie-points used for MIS 5.

\begin{tabular}{|c|c|c|}
\hline Depth (mbsf) & Age (ka) & Tie-point \\
\hline 0.03 & 1.045 & Radiocarbon dating \\
\hline 0.56 & 2.565 & Radiocarbon dating \\
\hline 1.07 & 4.455 & Radiocarbon dating \\
\hline 1.43 & 5.755 & Radiocarbon dating \\
\hline 1.99 & 7.970 & Radiocarbon dating \\
\hline 3.23 & 11.550 & Holocene base \\
\hline 3.63 & 12.650 & Younger Dryas base \\
\hline 4.31 & 14.650 & Bolling-Allerød base \\
\hline 7.35 & 19.730 & Radiocarbon dating \\
\hline 9.68 & 23.340 & IS2 \\
\hline 12.40 & 27.780 & IS3 \\
\hline 13.16 & 28.900 & IS4 \\
\hline 14.46 & 32.500 & IS5 \\
\hline 14.88 & 33.740 & IS6 \\
\hline 15.90 & 35.480 & IS7 \\
\hline 17.34 & 38.220 & IS8 \\
\hline 18.64 & 40.160 & IS9 \\
\hline 19.24 & 41.460 & IS10 \\
\hline 20.20 & 43.340 & IS11 \\
\hline 21.80 & 46.860 & IS12 \\
\hline 23.16 & 49.280 & IS13 \\
\hline 24.86 & 54.220 & IS14 \\
\hline 26.00 & 55.800 & IS15 \\
\hline 27.06 & 58.280 & IS16 \\
\hline 27.76 & 59.440 & IS17 \\
\hline 30.38 & 64.650 & IS18 \\
\hline 33.12 & 73.100 & S20 top \\
\hline 33.50 & 74.950 & S20 base \\
\hline 33.88 & 77.200 & S21 top \\
\hline 34.28 & 78.550 & S21 base \\
\hline 36.68 & 85.500 & S22 top \\
\hline 37.24 & 88.400 & S22 base \\
\hline 38.54 & 90.800 & S23 top \\
\hline 40.86 & 104.800 & S24 top \\
\hline
\end{tabular}


Table 4. contd...

\begin{tabular}{|c|c|c|}
\hline Depth $(\mathbf{m b s f})$ & Age (ka) & Tie-point \\
\hline \hline 41.50 & 106.100 & S24 base \\
\hline 42.22 & 108.750 & S25 top \\
\hline 42.58 & 110.950 & S25 base \\
\hline 43.82 & 115.550 & S26 top \\
\hline 46.40 & 128.140 & MIS 6/5 boundary \\
\hline
\end{tabular}

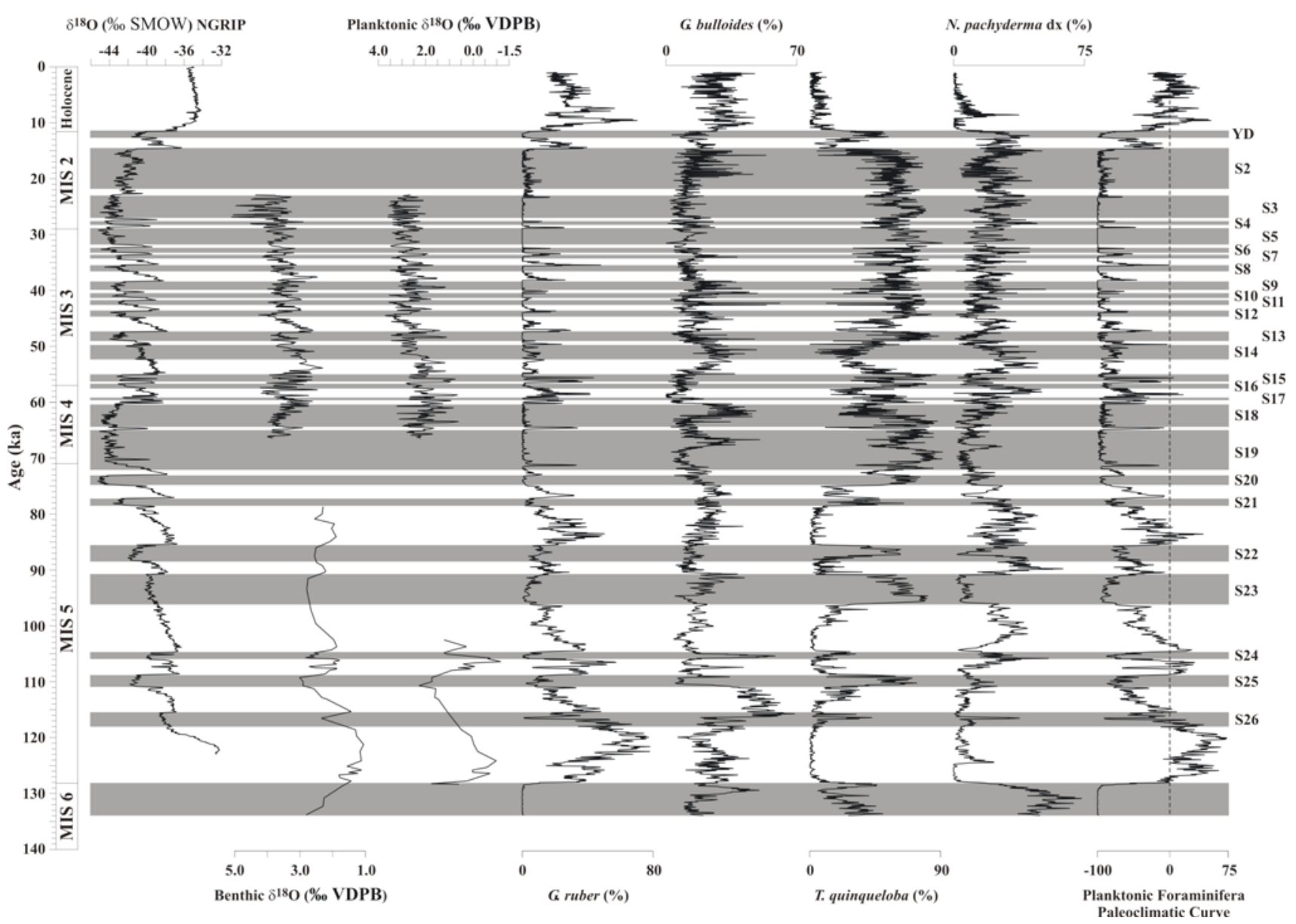

Fig. (2). Downcore variations of geochemical data and planktonic foraminifera species at ODP Site 963, plotted versus calibrated age (kyr) and showing the marine isotopic stratigraphic framework. From the left, oxygen isotopic record of Greenland ice cores [50]; benthic and planktonic oxygen isotopic records at ODP Site 963 [14, 16]; distribution patterns of G. ruber, G. bulloides, T. quinqueloba and N. pachyderma $\mathrm{dx}$ at ODP Site 963, expressed as percentage values [13, 14, 16, 39]; downcore variations of the planktonic foraminifera paleoclimatic curve. Light grey bands mark Stadials, white bands mark Interstadials. S26-S2 show the sequence of Stadials across the sequence. YD: Younger Dryas.

\section{DISCUSSION}

\subsection{Suborbital Climatic Oscillation}

The whole sequence of Stadial (S) and Interstadial (IS) oscillations since the last interglacial $(\sim 130 \mathrm{ka})$ is shown in Figs. (2 and 3), which have been built by joining data from Site 963 Hole D and Hole A [13-16, 37-39]. The climatic fluctuations are identified by variations in the planktonic foraminifera and oxygen isotopic curves (Fig. 2). Intersta- dials are marked by abundance peaks of the warm water species G. ruber (Fig. 2). Cold water species G. bulloides, $N$. pachyderma $\mathrm{dx}$ and $T$. quinqueloba replace one each other during Stadials, even if indeed T. quinqueloba abundance peaks mark most of the Stadials (Fig. 2).

Less regular is the situation looking at coccolithophore assemblages. Placoliths abundance peaks fall in coincidence of many Stadials of MIS 5, mainly controlled by increases in percentage values of $G$. muellerae $[14,38]$ and of the Younger Dryas (Fig. 3). During the last glacial period, the 


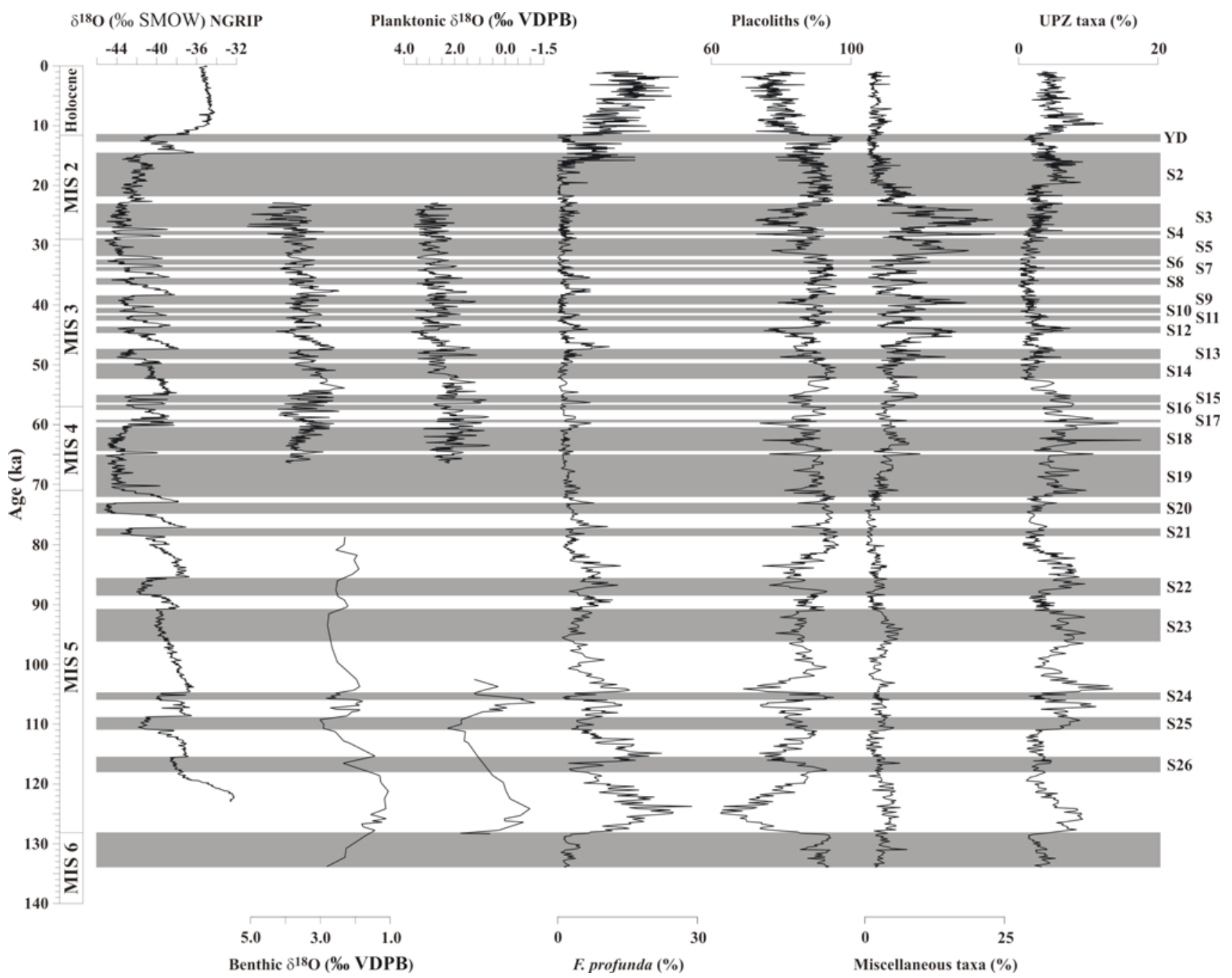

Fig. (3). Downcore variations of geochemical data and coccolithophore taxa and groups at ODP Site 963, plotted versus calibrated age (kyr) and showing the marine isotopic stratigraphic framework. From the left, oxygen isotopic record of Greenland ice cores [50]; benthic and planktonic oxygen isotopic records at ODP Site $963[14,16]$; distribution patterns of $F$. profunda, placoliths, miscellaneous and UPZ taxa at ODP Site 963, expressed as percentage values [13-16, 39]. Light grey bands mark Stadials, white bands mark Interstadials. S26-S2 show the sequence of Stadials across the sequence. YD: Younger Dryas.

interval between MIS 4 and MIS 2, many Stadials are characterized by increased relative abundances of Miscellaneous taxa (Fig. 3), such as Helicosphaera carteri and S. histrica [39]. Florisphaera profunda peaks can be seen in most of the Interstadials throughout the sedimentary sequence (Fig. 3) and remarkably abundance fluctuations of this species gather the subtle oscillations occurred during the Holocene [15]. Increased abundance of UPZ taxa are recorded in both Stadials and Interstadials, but a significant occurrence is recorded at the beginning of both interglacials, MIS 5 and Holocene (Fig. 3).

The whole sequence of suborbital climatic fluctuations has already been found in the western Mediterranean (Alboran) Sea by alkenone-derived SSTs and is even extended down to the past $250 \mathrm{kyr}$ [51]. The fact that a wide sector of the Mediterranean Sea shows the same response to suborbital climatic fluctuations, in terms of SST, provides a robust support to the possible teleconnection with the Greenland and North Atlantic regions. In other words, there is not a hydrological-mediated response (e.g. local upwelling and mesoscale cyclonic or anticyclonic gyres), but a unique regional behaviour, likely due to atmospheric phenomena, for instance the Polar Vortex expansion during Stadials [8, 59].

There is not any direct evidence of the occurrence of suborbital climatic fluctuations in micropaleontological and geochemical studies carried out in the eastern Mediterranean Sea. However, physico-chemical properties (e.g. salinity and/or temperature), speed, ventilation and the vertical location of the LIW, the intermediate water mass formed in the Rhodes gyre area, seem to change during Stadial/Interstadial oscillations over the past $130 \mathrm{ka}$, both in the Sicily Channel and the Corsica Trough [14, 16, 60]. Further investigation is needed to understand processes that acted in the eastern Mediterranean basin, among others the role of the African monsoon variability in driving and/or preconditioning LIW formation processes.

\subsection{Paleoproductivity Variations}

Throughout the ODP 963 site sedimentary sequence there is a link between Stadial/Interstadial fluctuations and 
changes in productivity levels and the vertical structure of the water column. Interstadials are characterized by oligotrophic surface waters (peaks of G. ruber and at least partially of the coccolithophore UPZ taxa) and a deep nutricline (peaks of $F$. profunda). Increased surface productivity can be inferred for most stadials on the basis of the enhanced percentage abundance of $G$. bulloides, $N$. pachyderma dx, T. quinqueloba and placoliths (Figs. 2 and 3). Indeed, the in depth evaluation of the distribution pattern of these taxa during the suborbital fluctuations of the last glacial period highlights a more complicated situation during each Stadial/Interstadial cycle [39]: surface oligotrophy and a deep nutricline confined to the lower part of interstadials; increased productivity after blooms, during the upper part of Interstadials; a shallow nutricline during Stadials, possibly characterized by disturbance in surface productivity, that is reduced productivity levels with respect to the upper Interstadial phase.

Looking back at the MIS 5 interval, there is little doubt that the three-scenarios interpretation can also be adopted, at least since Is 24 (between S 25 and S 24), where $N$. pachyderma $\mathrm{dx}$ peaks cover the upper part of Interstadials (Fig. 2) and Stadials are characterized by marked abundance fluctuations of placoliths (Fig. 3). Thus, the real Stadial/high surface productivity and Interstadial/low surface productivity coupling seems to be restricted to the lowermost part of MIS 5 , up to S 25 that marks the decline of arboreal pollen in southern Europe [61, 62], and the last deglaciation (BollingAllerød and Younger Dryas).

The same productivity style across Stadial/Interstadial oscillations observed in the Sicily Channel and the Alboran Sea suggests the influence of sea level fluctuations and of the inflow through the Gibraltar strait of fresher water of polar origin on marine planktonic ecosystems [39]. In fact, the lower global sea level during the last glacial may have led to a strong decrease in the Atlantic/Mediterranean exchange and a subsequent density gradient increase between surface and subsurface water [63, 64], significantly suppressing vertical mixing. The same effect may be ascribed to the inflow of fresher water of polar origin during Stadials that is documented by light oxygen isotopic values in planktonic foraminifera shells in coincidence of most of North Atlantic Heinrich events $[16,65]$. Both these processes are suitable to explain the disturb in surface productivity in Stadials of the upper part of MIS 5 in the Sicily Channel record, given that the S 25 event marks the first significant sea level drop [66, 67] and the first significant occurrence of ice rafted detritus in the North Atlantic record [68] since the MIS 6/MIS 5 transition.

One of the main avenues of research in paleoceanography is the use of microfossil assemblages for quantitative reconstructions by transfer functions [69]. Following the approach of Beaufort et al. [70], the study of coccolithophore assemblages from the Sicily Channel surface sediments led to the identification of a close relationship between percentage values of $F$. profunda and productivity levels deduced by satellite imagery [15, 71]. The output transfer function allows $F$. profunda percentage values to be changed into net primary production data $(\mathrm{mgC}$ $\mathrm{x} \mathrm{m}^{-2} \mathrm{x} \mathrm{yr}^{-1}$ ) through a natural logarithm formula. Interestingly, the same kind of formula has later proven to be suitable to determine net primary production data by $F$. profunda percentage values in the eastern Mediterranean Sea [72].

\section{CONCLUSION}

Sub-centennial-scale micropaleontological and geochemical records have been presented from the Sicily Channel ODP Site 963. They show the whole sequence of Stadial and Interstadial oscillations since the last interglacial ( 130 ka), from S 26 to S2 and also including Bolling-Allerød and Younger Dryas. The fact that the same sequence has been found by alkenone-based SST in the Alboran Sea strongly support the occurrence of teleconnection between the western-central Mediterranean Sea and the Greenland/North Atlantic region.

The ODP 963 record shows a permanent link between Stadial/Interstadial fluctuations and changes in productivity levels and the vertical structure of the water column. The three-scenarios interpretation adopted for each Stadial/Interstadial oscillation during the last glacial period [39] may also be extended down to Is $24(\sim 110 \mathrm{ka})$. Disturbance in productivity produced by low global sea level and inflow of fresher water of polar origin is compatible with this extension given that the $S 25$ event marks the first significant sea level drop $[66,67]$ and the first significant occurrence of ice rafted detritus in the North Atlantic record [68] since the MIS 6/MIS 5 transition.

In conclusion, investigations carried out on the Site 963 record provide a valuable key for the comprehension of paleoceanographic variations triggered by high-frequency climatic fluctuations. The investigations also provide a valuable dataset to be compared by studies from different Mediterranean areas.

\section{CONFLICT OF INTEREST}

The authors confirm that this article content has no conflicts of interest.

\section{ACKNOWLEDGEMENTS}

We are grateful to three anonymous reviewers for their valuable comments and suggestions. The research has benefit from funding from MIUR ex $60 \%$ grants to E. Di Stefano.

\section{REFERENCES}

[1] Kullenberg B. On the salinity of the water contained in marine sediments. Goeteborgs K. Vetensk. Vitterhets-Samh. Handl. US: Elanders boktr 1952; 6: 3-37.

[2] Rohling EJ, Gieskes WWC. Late Quaternary changes in Mediterranean Intermediate Water density and formation rate. Paleoceanography 1989; 4: 531-45.

[3] Castradori D. Calcareous nannofossils and the origin of eastern Mediterranean sapropels. Paleoceanography 1993; 8: 459-71.

[4] Incarbona A, Ziveri P, Sabatino N, Salvagio Manta D, Sprovieri M. Conflicting coccolithophore and geochemical evidence for productivity levels in the Eastern Mediterranean sapropel S. Mar Micropaleontol 2011; 81: 131-43.

[5] Rossignol-Strick M. African monsoons, an immediate response to orbital insolation. Nature 1983; 30: 446-9. 
[6] Rohling EJ, Cane TR, Cooke S, et al. African monsoon variability during the previous interglacial maximum. Earth Planet Sci Lett 2002; 202: 61-75.

[7] Cacho I, Grimalt JO, Pelejero C, et al. Dansgaard-Oeschger and Heinrich event imprints in Alboran Sea paleotemperatures. Paleoceanography 1999; 14: 698-705.

[8] Cacho I, Grimalt JO, Sierro FJ, Shackleton N, Canals M. Evidence for enhanced Mediterranean thermohaline circulation during rapid climatic coolings. Earth Planet Sci Lett 2000; 183: 417-29.

[9] Cacho I, Grimalt JO, Canals M, et al. Variability of the western Mediterranean Sea surface temperature during the last 25,000 years and its connection with the Northern Hemisphere climate changes. Paleoceanography 2001; 16: 40-52.

[10] Cacho I, Grimalt JO, Canals M. Response of the Western Mediterranean Sea to rapid climatic variability during the last 50,000 years: a molecular biomarker approach. J Mar Syst 2002; 33: 253-72.

[11] Gasparini GP, Ortona A, Budillon G, Astraldi M, Sansone E. The effect of the Eastern Mediterranean Transient on the hydrographic characteristics in the Strait of Sicily and in the Tyrrhenian Sea. Deep-Sea Res Pt I 2005; 52: 915-35.

[12] Gačić M, Schroeder K, Civitarese G, et al. Salinity in the Sicily Channel corroborates the role of the Adriatic-Ionian Bimodal Oscillating System (BiOS) in shaping the decadal variability of the Mediterranean overturning circulation. Ocean Sci 2013; 9: doi:10.5194/os-9-83-2013.

[13] Sprovieri R, Di Stefano E, Incarbona A, Gargano ME. A highresolution record of the last deglaciation in the Sicily Channel based on foraminifera and calcareous nannofossil quantitative distribution. Palaeogeogr Palaeoclimatol Palaeoecol 2003; 202: 119-42.

[14] Sprovieri R, Di Stefano E, Incarbona A, Oppo DW. Suborbital climate variability during Marine Isotopic Stage 5 in the Mediterranean Basin: evidence from planktonic foraminifera and calcareous nannofossil relative abundance fluctuations. Quat Sci Rev 2006; 25: 2332-42.

[15] Incarbona A, Di Stefano E, Patti B, et al. Holocene millennial-scale productivity variations in the Sicily Channel (Mediterranean Sea). Paleoceanography $2008 ; 23: 1-18$.

[16] Sprovieri M, Di Stefano E, Incarbona A, et al. Centennial- to millennial-scale oscillations in the Central-Eastern Mediterranean Sea between 20,000 and 70,000 years ago: Evidence from a highresolution geochemical and micropaleontological record. Quat Sci Rev 2012; 46: 126-35

[17] Millot C. Circulation in the Western Mediterranean Sea. Oceanol Acta 1987; 10: 143-9.

[18] Robinson AR, Sellschopp J, Warn-Varnas A, et al. The Atlantic Ionian Stream. J Mar Syst 1999; 20: 129-56.

[19] Béranger K, Mortier L, Gasparini G-P, et al. The dynamics of the Sicily Strait: a comprehensive study from observations and models. Deep-Sea Res II 2004; 51: 411-40.

[20] Onken R, Robinson AR, Lermusiaux PFJ, Haley Jr PJ, Anderson LA. Data-driven simulations of synoptic circulation and transports in the Tunisia-Sardinia-Sicily region. J Geophys Res 2003; 108 : 8123-36.

[21] Lermusiaux PFJ, Robinson AR. Features of dominant mesoscale variability, circulation patterns and dynamics in the Strait of Sicily. Deep-Sea Res I 2001; 48: 1953-97.

[22] Ovchinnikov IM. The formation of Intermediate Water in the Mediterranean. Oceanology 1984; 24: 168-73.

[23] POEM group. General circulation of the Eastern Mediterranean. Earth-Sci Rev 1992; 32: 285-309.

[24] Bethoux JP. Budgets of the Mediterranean Sea. Their dependance on the local climate and on the characteristics of the Atlantic waters. Oceanol Acta 1979; 2: 157-63.

[25] Sarmiento J, Herbert T, Toggweiler JR. Mediterranean nutrient balance and episodes of anoxia. Glob Biogeochem Cycles 1988; 2 : 427-44.

[26] Krom MD, Kress N, Brenner S, Gordon LI. Phosphorus limitation of primary productivity in the Eastern Mediterranean sea. Limnol Oceanogr 1991; 36: 424-32.

[27] Krom MD, Emeis K-C,Van Cappellen P. Why is the Eastern Mediterranean phosphorus limited? Prog Oceanogr 2010; 85: 23644.

[28] Klein P, Coste P. Effects of wind stress variability on nutrient transport into the mixed layer. Deep-Sea Res 1984; 31: 21-37.
[29] D'Ortenzio F, Ribera d'Alcalà M. On the trophic regimes of the Mediterranean Sea: a satellite analysis. Biogeosciences 2009; 6: 139-48.

[30] Josey SA, Somot S, Tsimplis M. Impacts of atmospheric modes of variability on Mediterranean Sea surface heat exchange. J Geophys Res 2011; 116: doi:10.1029/2010JC006685.

[31] Bolle H-J. Mediterranean Climate - Variability and Trends. Berlin: Springer 2003; pp. 1-372.

[32] Böttcher ME, Rinna J, Warning B, et al. Geochemistry of sediments from the connection between the western and the eastern Mediterranean Sea (Strait of Sicily, ODP Site 963). Palaeogeogr Palaeoclimatol Palaeoecol 2003; 190: 165-94.

[33] Emeis K-C, Robertson AHF, Richter C, et al. Site 963 Cores. Proceedings ODP, Initial Report 160. TX (Ocean Drilling Program): College Station 1996; pp. 535-84.

[34] Howell MW, Thunell RC, Di Stefano E, et al. Stable isotope chronology and paleoceanographic history of Sites 963 and 964, Eastern Mediterranean sea. In: Emeis, K-C., Robertson, AHF, Richter C, Camerlenghi A. Eds, Proc Ocean Drill Program, Sci Results 1998; 160: 167-80.

[35] Tamburrino S, Insinga DD, Sprovieri M, Petrosino P, Tiepolo M. Major and trace element characterization of tephra layers offshore Pantelleria Island: Insights into the last $200 \mathrm{ka}$ of volcanic activity and contribution to the Mediterranean tephrochronology. J Quat Sci 2012; 27: 129-40.

[36] Keller J, Ryan WBF, Ninkovich D, Altherr R. Explosive volcanic activity in the Mediterranean over the past 20000 years as recorded in deep-sea sediments. Geol Soc Am Bull 1978; 89: 591-604.

[37] Di Stefano E, Incarbona A. High resolution palaeoenvironmental reconstruction of ODP Hole-963D (Sicily Channel) during the last deglaciation, based on calcareous nannofossils. Mar Micropaleontol 2004; 52: 241-54.

[38] Incarbona A, Bonomo S, Di Stefano E, et al. Millennial-scale paleoenvironmental changes in the central Mediterranean during the Last Interglacial: comparison with European and Mediterranean records. Geobios 2010; 43: 111-22.

[39] Incarbona A, Sprovieri M, Di Stefano A, et al. Productivity modes in the Mediterranean Sea during Dansgaard-Oeschger $(20,000$ 70,000 yr ago) oscillations. Palaeogeogr Palaeoclimatol Palaeoecol 2013; 392: 128-37.

[40] Bown PR, Young JR. Techniques. In: Bown, P.R. (Ed.), Calcareous Nannofossil Biostratigraphy. Dordrecht, Boston, London: Kluwer Academic Publishers 1998; pp. 16-32.

[41] Young JR, Geisen M, Cros L, et al. A guide to extant coccolithophore taxonomy. J Nannoplankton Res Special Issue 2003; 1: 1-121.

[42] Young JR. Functions of coccoliths. In: Winter A, Siesser WG, Eds. Coccolithophores. Cambridge: Cambridge University Press 1994; pp. 63-82.

[43] Incarbona A, Ziveri P, Di Stefano E, et al. The Impact of the Little Ice Age on coccolithophores in the Central Mediterranean Sea. Clim Past 2010; 6: 795-805.

[44] Tangen K, Brand LE, Blackwelder PL, Guillard RRL. Thoracosphaera heimii (Lohmann) Kamptner is a dinophyte: observations on its morphology and life cycle. Mar Micropaleontol 1982; 7: 193-212.

[45] Bolli HM, Saunders JB, Perch-Nielsen K. Plankton Stratigraphy. New York: Cambridge University Press 1985; pp. 1-1032.

[46] Hemleben C, Spindler M, Anderson OR. Modern planktonic foraminifera. New York: Springer-Verlag 1989; pp. 1-363.

[47] Corselli C, Principato MS, Maffioli P, Crudeli D. Changes in planktonic assemblages during sapropel S5 deposition: Evidence from Urania basin Area, eastern Mediterranean. Paleoceanography 2002; 17: 1-28.

[48] Spötl C, Vennemann TW. Continuous-flow isotope ratio mass spectrometric analysis of carbonate minerals. Rapid Commun Mass Spectrom 2003; 17: 1004-6.

[49] Ostermann DR, Curry WB. Calibration of stable isotopic data: An enriched $\mathrm{O}$ standard used for source gas mixing detection and correction. Paleoceanography 2000; 15: 3, 353-60.

[50] North Greenland Ice Core Project Members. High-resolution record of Northern Hemisphere climate extending into the last interglacial period. Nature 2004; 431: 148-51.

[51] Martrat B, Grimalt JO, Lopez-Martinez C, et al. Abrupt Temperature Changes in the Western Mediterranean over the Past 250,000 Years. Science 2004; 306: 1762-5. 
[52] Andersen KK, Svensson AM, Johnsen SJ, et al. The Greenland Ice Core Chronology 2005, 15-42 ka. Part 1: constructing the time scale. Quat Sci Rev 2006; 25: 3246-57.

[53] Svensson AM, Andersen KK, Bigler M, et al. The Greenland Ice Core. Chronology 2005, 15-42 ka.Part 2: comparison to other records. Quat Sci Rev 2006; 25: 3258-67.

[54] Svensson A, Andersen KK, Bigler M, et al. A 60,000 year Greenland stratigraphic ice core chronology. Clim Past 2008; 4: 4757.

[55] Sakamoto T, Janecek T, Emeis K-C. Continuous sedimentary sequences from the eastern Mediterranean sea: composite depth sections. . In: Emeis K-C, Robertson AHF, Richter C, Camerlenghi A, Eds. Proc Ocean Drill Program, Sci Results 1998; 160: 37-59.

[56] Emeis K-C, Robertson AHF, Richter C, et al. Site 963. Proceedings ODP, Initial Report 160. TX: College Station Ocean Drill Prog 1996; pp. 55-84.

[57] Rohling EJ, Hayes A, De Rijk S, et al. Abrupt cold spells in the northwest Mediterranean. Paleoceanography 1998; 13: 316-22.

[58] Scaillet S, Vita-Scaillet G, Rotolo SG. Millennial-scale phase relationship between ice-core and Mediterranean marine records: insights from high-precision 40Ar/39Ar dating of the Green Tuff of Pantelleria, Sicily Strait. Quat Sci Rev 2013; 78: 141-54.

[59] Moreno A, Cacho I, Canals M, et al. Links between marine and atmospheric processes oscillating on a millennial time-scale. A multi-proxy study of the last 50,000 yr from the Alboran Sea (Western Mediterranean Sea). Quat Sci Rev 2005; 24: 1623-36.

[60] Toucanne S, Jouet G, Ducassou E, et al. A 130,000-year record of Levantine Intermediate Water flow variability in the Corsica Trough, western Mediterranean Sea. Quat Sci Rev 2012; 33: 55-73.

[61] Sanchez Goñi MF, Loutre MF, Crucifix M, et al. Increasing vegetation and climate gradient in western Europe over the Last Glacial Inception (122-110 ka): data model comparison. Earth Planet Sci Lett 2005; 231: 111-30.

[62] Brauer A, Allen JRM, Mingram J, et al. Evidence for last interglacial chronology and environmental change from Southern Europe. Proc Natl Acad Sci USA 2007; 104: 450-5.

[63] Mikolajewicz U. Modeling Mediterranean Ocean climate of the Last Glacial Maximum. Clim Past 2011; 7: 161-80.

[64] Rogerson M, Rohling EJ, Bigg G, Ramirez J. Paleoceanography of the Atlantic-Mediterranean exchange: Overview and first quantitative assessment of climatic forcing. Rev Geophys 2012; 50: doi:10.1029/2011RG000376.

[65] Sierro FJ, Hodell DA, Curtis JH, et al. Impact of iceberg melting on Mediterranean thermohaline circulation during Heinrich Events. Paleoceanography 2005; 20: doi:10.1029/2004PA001051.

[66] Waelbroeck C, Labeyrie L, Michel E, et al. Sea-level and deep water temperature changes derived from benthic foraminifera isotopic records. Quat Sci Rev 2002; 21: 295-305.

[67] Rohling EJ, Grant K, Bolshaw M, et al. Antarctic temperature and global sea level closely coupled over the past five glacial cycles. Nat Geosci 2009; 2: 500-4.
[68] McManus JF, Oppo DW, Cullen JL. A 0.5-Million-Year Record of Millennial-Scale Climate Variability in the North Atlantic. Science 1999; 283: 971-5.

[69] Guiot J, de Vernal A. Transfer Functions: Methods for Quantitative Paleoceanography Based on Microfossils. In: Hillaire-Marcel C, de Vernal A, Eds. Proxies in Late Cenozoic Paleoceanography. the Netherlands: Elsevier 2007; pp. 523-63.

[70] Beaufort L, Lancelot Y, Camberlin P, et al. Insolation Cycles as a Major Control of Equatorial Indian Ocean Primary Production. Science 1997; 278: 1451-4.

[71] Incarbona A, Bonomo S, Di Stefano E, et al. Calcareous nannofossil surface sediment assemblages from the Sicily Channel (central Mediterranean Sea): palaeoceanographic implications. Mar Micropaleontol 2008; 67: 297-309.

[72] Grelaud M, Marino G, Ziveri P, Rohling EJ. Abrupt shoaling of the nutricline in response to massive freshwater flooding at the onset of the last interglacial sapropel event. Paleoceanography 2012; 27: DOI: $10.1029 / 2012 P A 002288$

[73] Pujol C, Vergnaud-Grazzini C. Distribution patterns of live planktonic foraminifera as related to regional hydrography and productive system of the Mediterranean Sea. Mar Micropaleontol 1995; 25: 187-217.

[74] Žarić S, Donner B, Fischer G, Mulitza S, Wefer G. Sensitivity of planktic foraminifera to sea surface temperature and export production as derived from sediment trap data. Mar Micropaleontol 2005; 55: 75-105.

[75] Rigual-Hernández AS, Sierro FJ, Bárcena MA, Flores J-A, Heussner S. Seasonal and interannual changes of planktic foraminiferal fluxes in the Gulf of Lions (NW Mediterranean) and their implications for paleoceanographic studies: Two 12-year sediment trap records. Deep-Sea Res 2012; 66: 26-40.

[76] Broerse ATC, Ziveri P, van Hinte JE, Honjo S. Coccolithophore export production, species composition, and coccolith-CaCO3 fluxes in the NE Atlantic $\left(34^{\circ} \mathrm{N} 21^{\circ} \mathrm{W}\right.$ and $\left.48^{\circ} \mathrm{N} 21^{\circ} \mathrm{W}\right)$. Deep-Sea Res II 2000; 47: 1877-905

[77] Flores J-A, Bárcena MA, Sierro FJ. Ocean-surface and wind dynamics in the Atlantic Ocean off Northwest Africa during the last 140,000 years. Palaeogeogr Palaeoclimatol Palaeoecol 2000; 161: 459-78.

[78] De Bernardi B, Ziveri P, Erba E, Thunell RC. Coccolithophore export production during the 1997-1998 El Niño event in Santa Barbara Basin (California). Mar Micropaleontol 2005; 55: 107-25.

[79] Molfino B, McIntyre A. Precessional forcing of nutricline dynamics in the Equatorial Atlantic. Science 1990; 249: 766-9.

[80] Andruleit H, Stäger S, Rogalla U, Cepek P. Living coccolithophores in the northern Arabian Sea: ecological tolerances and environmental control. Mar Micropaleontol 2003; 49: 157-81.

[81] Boeckel B, Baumann K-H. Distribution of coccoliths in surface sediments of the south-eastern South Atlantic Ocean: ecology, preservation and carbonate contribution. Mar Micropaleontol 2004; 51: 301-20. 